\title{
THE BODY OF ART
}

\section{Shelton Waldrep (a)}

(a) University of Southern Maine. Portland, USA. Email: waldrep[at]maine.edu

\begin{abstract}
As part of a larger study on the mainstreaming of pornography in contemporary film and television, this essay attempts to examine and extend our vocabulary for discussing visual representations of the human body by revisiting Kenneth Clark's important study The Nude from 1972. Clark's book provides a history of the male and female nude in two- and three-dimensional art from Ancient Egypt and Greece to the Renaissance and beyond. This essay focuses on places within his analysis that are especially generative for understanding pornography such as the importance of placing the nude form within a narrative (Venus is emerging from her bath, for example) or attempts by artists to suggest movement within static forms. The essay places Clark's rich typology in conversation with other thinkers, such as Fredric Jameson, Erwin Panofsky, E. H. Gombrich, and Michel Foucault. The piece ends with a discussion of androgyny and hermaphroditism as they relate to the expression of gender in plastic art, especially the notion that all representations of the body necessarily include a gender spectrum within one figure. Artists whose work is looked at in some detail include Da Vinci, Michelangelo, and Donatello.
\end{abstract}

Keywords

Body; art; pornography; narrative; gender

This work is licensed under a Creative Commons «Attribution» 4.0 International License. 


\section{ТЕЛО В ИСКУССТВЕ}

\section{Уолдреп Шелтон (a)}

(a) Университет Южного Мэна. Портленд, США. Email: waldrep[at]maine.edu

\section{Аннотация}

Будучи частью более обширного исследования, посвященного проникновению порнографии в современные кинематограф и телевидение, данное эссе представляет собой попытку проанализировать и расширить наш лексикон для обсуждения визуальных образов человеческого тела, пересматривая важное исследование Кеннета Кларка «Нагота в искусстве» 1972 года. Труд Кларка рассказывает об истории изображения нагих мужчин и женщин в двух- и трехмерном искусстве от Древнего Египта и Греции до Ренессанса и далее. Это эссе сосредотачивается на тех аспектах его анализа, которые особенно ценны для понимания порнографии: таких, как значение включения обнаженной натуры в повествование (Венера, выходящая из ванны, к примеру) или попытки художников предложить движение в пределах статических форм. В эссе богатая типология Кларка осмысляется с подходами других мыслителей, таких как Фредрик Джеймисон, Эрвин Панофский, Эрнст Гомбрих и Мишель Фуко. Работа завершается обсуждением андрогинности и гермафродитизма в связи с выражением гендера в пластическом искусстве, в частности, с представлением о том, что все изображения тела обязательно включают в себя гендерный спектр в рамках одной фигуры. В числе художников, чьи работы рассматриваются в деталях, - да Винчи, Микеланджело и Донателло.

\section{Ключевые слова}

Телесность; искусство; порнография; нарратив; гендер

Это произведение доступно по лицензии Creative Commons «Attribution» («Атрибуция») 4.0 Всемирная 


\section{INTRODUCTION}

In a meditation on the body and narratology, Fredric Jameson discusses the body of Christ in the Western art-historical canon and the many ways that it allowed for a variety of theatricalized scenes to be explored. Christ's body not only allowed for representation of the body "from its birth to its agony and death" (p. 8) but also for sexuality. As Eve Kosofsky Sedgwick discusses in Epistemology of the Closet, the nude or semi-nude body of Christ allowed for a visible representation of gay male desire, an acceptable male body to view and worship (p. 148). It is not by accident that Oscar Wilde returns to Christ, in a sense, in his post-prison writings. For Jameson, religion as the subject matter for art allowed for a way to narrativize visual art via the theatrical:

Christ's body ... served as the laboratory for innumerable experiments in the representation of the body in all its postures and potentialities ... enabl[ing] the theatrical staging of equally innumerable dramatic-which is to say narrativescenes (p. 8).

Ultimately, for Jameson, this theatricality could be termed "cinematographic" (p. 8) ${ }^{1}$. Jameson goes on to focus specifically on Peter Paul Rubens' Samson and Delilah (1609-1610). This particular painting shows a post-coital Samson asleep, his massive body arraigned across the painting, his torso tossed onto Delilah's, his strong left arm acting as a diagonal element that crosses nearly half the painting. That arm, as Jameson notes, is "more materialist and carnal in its sheer strength as well as its abandon, than Christ's whole body" (p. 16). The dead weight of the Christ of the pietà or the descent from the cross is nothing in comparison. The painting "virtually reeks of sex" (p. 16) and in that sense outdoes anything by Caravaggio or Rubens. If Christ's body is other than human, then Samson is a Nietzschean Übermensch, a body that expresses, finally, not so much sex as the life force itself (p. 17). Paintings of the Renaissance often represent a sort of cinematic "freeze frame," as Jameson calls it, or a tableau (p. 19). The artists attempted to represent a particular "moment" in time, however malleable that might be. In this painting, Rubens is not interested so much in "linear temporality" as in an "absolute" time, a conceptual time that lies outside of the regular definition (p. 19), or perhaps allows for several different timelines to exist simultaneously. Perhaps the painting enacts the very question of time, or its time, and therefore achieves a "raw immedi-

1 In his book on film, Signatures of the Visible, James emphatically notes that " $\mathrm{t}]$ he visual is essentially pornographic..." "Pornographic films are thus only the potentiation of films in general, which ask us to stare at the world as though it were a naked body" (p. 1) 
acy" (p. 26), one that allows for conceptual thinking "in a painterly way" (p. 28). From this line of thought, as Jameson concludes:

Il n'y a pas de rapport sexuel: through this breach or gap now stream all the ideological binaries piling up like pus or toxin in the naturalization of sex: the battle of the sexes . . their virtual transformation into two species; but also-mind or spirit versus body or matter . . the politics versus sexuality (public versus private)... In these oppositions the ethical bouncing ball touches first on one then the other, passing back and forth from one term to the other (bound together as they are by History), now certifying one as good and the other evil until the inevitable alternation and reversal, thereby perpetuating the timeless Apollonian stillness of the two eternal figures. (pp. 28-29)

Jameson's reading of this particular painting by Rubens attempts to understand how time functions within it, and therefore, how narrative elements work here. Jameson seems to imply that Rubens' solution is superior to that of the painters of the Renaissance who saw narrative as a sort of frozen time - that they were only able to think in a mostly literal way. But a central tenant of Walter Isaacson's Leonardo da Vinci is that the great artist's paintings are not only the result of his scientific observation, but that they are characterized by his ability always to fold complex notions about time (and space) into his paintings. As early as The Annunciation (1472-1475) Da Vinci represents the angel Gabriel as having just alighted within the garden walls. The grass blows forward, his sleeves flutter black as though from the breeze created by his flight (Isaacson, p. 59). Space suggests a narrative, a particular moment in time but also the moment before it as well. In the two versions of The Virgin of the Rocks, in the Louvre (1483-1486) and the National Gallery in London (1495-1508), Da Vinci represents not one moment but two: the baby St. John recognizes the Christ child who blesses him in return, while Mary attempts to enfold them both in protective gestures while the angel seems to communicate directly with the viewer. In the first version, he points to the Christ and looks directly at the viewer; in the second, he merely reacts to the scene as a whole (Isaacson, p. 230), likewise outside of it, in time, if not space. Even in the Mona Lisa (1503), Da Vinci gives us a figure whose presence seems both a part of a mythic past and almost eerily present as well-her eyes rendered with such attention to physiognomy and optics that they seem to move and adjust to us in ways that give them their famous immediacy. This effect, combined with the rare three-quarters view of the subject that Da Vinci had first used in Ginevra de'Benci (1474-1478) (Isaacson, p. 64), emphasizes the portrait's presence, its intimacy as a portrait that demands to be experienced in the here and now. 


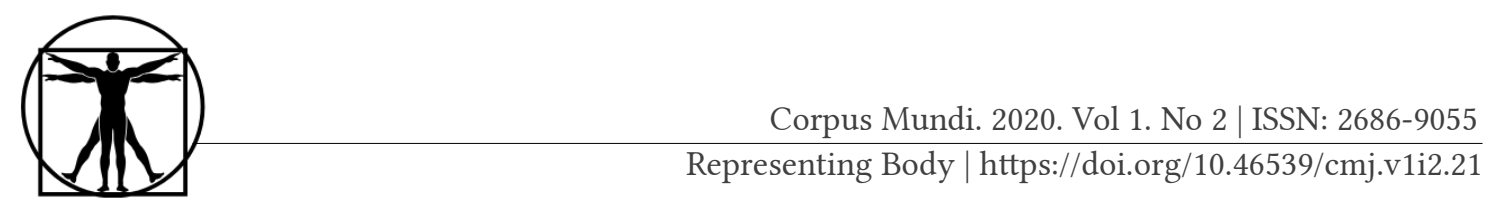

While Isaacson argues for seeing Da Vinci as a master of the ability to represent time in a complex way in his paintings, perhaps nowhere is this most obvious than in his fresco of the Last Supper (1490s). Though now a ruin, in its original form, the fresco could be read from left to right and represented the apostles in four groups of three figures each. Each group represents a slightly different moment in time, ranging from just before Christ's announcement that one of them has betrayed him, to the moment during the reaction to his statement, and just after. Christ himself seems to represent the actual moment of speech, his mouth still slightly open, while his hands gesture toward the bread and wine, whose full significance is yet to come. While other paintings by Leonardo are often read from left to right in a complex clockwise direction that emphasizes their spiral organization, this painting is rectilinear and attempts to reference the space of the refectory where it is located. There are multiple spatial tricks that try to make the fresco's illusion of space and architecture seem like an extension of the room it is in. The problem for Da Vinci, however, is that viewers might stand at different places in a room, or in the case of this work, enter from a door on the right and then move to a table in front of it. That is, all paintings that attempt a realistic, even scientific, version of the world must also deal with the fact that one's sense of perspective shifts as one's position in front of the painting does. There are multiple places in Da Vinci's paintings where he seems to have been trying to combine perspectives, ultimately choosing which ones he wanted to make most important (Isaacson, p. 58). Some of the choices here result in some of the anomalies-the foreshortened ceiling, which creates a sense of depth using the theatrical trick of a steep incline (Isaacson, p. 289); the fact that the tapestries on either side of the table at which Christ and his apostles sit do not match up (p. 287); the shallow table at which they dine and from which they stare, theatrically on one side, at the audience, etc. (p. 289). Classical painting, in other words, was never perfectly seamless or symmetrical. It was more like cinema: a two-dimensional attempt to render not so much space as the movement through space; which is to say, perhaps, not space but time.

The subject matter of paintings, however, is figuration, which is to say, the body. Many of the effects of pornography in film are prefigured by the tradition of Western painting itself. For thousands of years, artists have tried, in sculpture, vases, two-dimensional art, to represent the body realistically, which has always meant representing the body in narrative. Pornography is nothing less than the attempt to give to the reality of the body a story that makes the actions of sex, in particular, visible and realis tic. 
As in a painting, the porn body is not naked, it is nude. This fact is one of the essential differences between porn and other genres or media that depict naked people. The nude actors of porn disrupt one of the joys of nakedness-its identification with averageness, its variety, the fact that a fairly randomized group of naked people of any sex or gender will provide variation. Porn, by contrast, is radically stylized-it pushes the actorly notion of types to an extreme and combines it with an idea borrowed from modeling that only certain body types are erotic. Any real eroticism might be in the crossover-actors or pseudo-actors who seem like porn stars but are safely in the mainstream. Porn never shows us the beauty and innocent carnality of nakedness-1960s Woodstock footage, say, or nudist beaches, or sexual situations that are not co-opted by the commercial and aesthetic dictates of porn-professionals or amateurs. How we talk about porn, therefore, is the problem of how to talk about the nude body as a form.

\section{THE NUDE AND THE NAKED}

In his classic study of the naked body in art, Kenneth Clark provides one of the few books that gives us a vocabulary for talking about the naked or nude body, the relationship between the parts and the whole, and the changing representations of the human body in art across time in both two- and three-dimensional representations. The Nude continues to be influential since its original publication and only grows more important as we deal with the rapid increase in the visual representation of the naked body. As Clark makes clear at the onset of his study, naked means unclothed but nude means "the body re-formed" (p. 3). Nude means proportion and shape as the naked body in real life usually lacks both (p. 5). Still, the representation of the nude body cannot be completely divorced from its erotic content, or its link in real life with the naked body (p. 8), though certainly the nude body can be used to represent many other emotions or ideas than that (p. 9). In tracing the origin of the nude, it is important not to underestimate the audacity of Greek sculpture in its radical belief in the unveiling of the human body. The lack of self-consciousness about the human form is, as Clark notes, related to the Greek philosophical and aesthetic belief in the centrality of the human to define the world. While Clark refers to this belief as a kind of "wholeness" (p. 24), a more accurate description might be that the human is the measure of all things - even Greek gods are given human characteristics (though often in a magnified way). The nude human body is a metonymy for the literary epics and tragedies, the architecture, and the philosophy of Ancient 


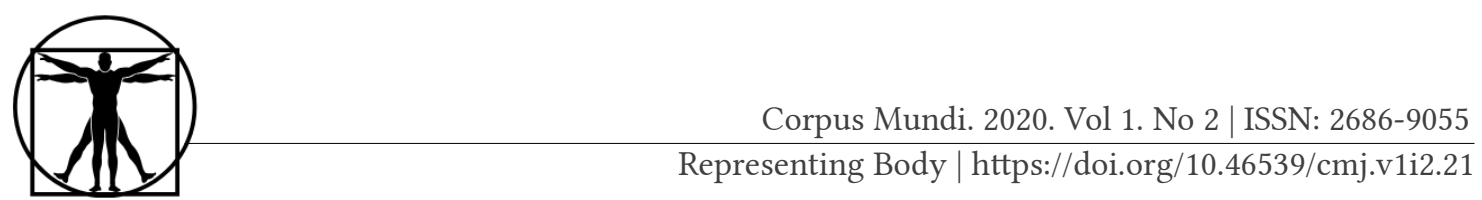

Greece in its belief in the power of human reason and in the body as the measure of the natural world. For Clark, what he calls "wholeness" reaches a peak with Praxiteles' Hermes (fourth century BC) when "physical beauty is one with strength, grace, gentleness, and benevolence" (p. 46). After that point, "we witness... the fragmentation of the perfect man, and the human body becomes either very graceful or very muscular or merely animal" (p. 46). The history of the nude after this point of early Greek sculptural perfection is, then, I would argue, at one with the history of pornography itself.

As Clark traces his way through art history, representations of the human body obviously change over time. Lysippos, "the last great name in Greek sculpture," "invented a new proportion, with smaller head, longer legs, and a slenderer body" (p. 48). Ancient writers note that he did a famous "figure of an athlete scraping himself, which was popular in ancient Rome. .." (p. 48). By the time the male nude is rediscovered in Renaissance Italy in the form of Donatello's David (1440s) the focus of the body's architecture has shifted from "the flat rectangular chest" to "the waist" as "the center of plastic interest" (p. 55) where it would remain throughout the Renaissance. The Cuirasse esthétique perfected by Polykleitos into a structure so perfect or harmonious that armor was based on it (p. 40) was supplanted by a form that, for Clark, makes Donatello's David seem more like a real boy, and not only in terms of youth. The Renaissance version of the male body reaches its perfection in Michelangelo's nudes, which for Clark contain the same celebration of the male body that one finds in classical Greek sculpture though his nudes are "unique" in their ability to be "both poignant and commanding" (p. 89).

While today the phrase "the nude" might, without any gender attached to it, assume to refer to the female nude, the opposite sex would have been assumed prior to the seventeenth century, which is why Clark's study begins with the male nude. Greek culture did not promote female public nudity in the same way as it did for men (only Sparta allowed women to show their legs or compete in athletic competitions almost nude) and Ancient Greek legends of Aphrodite suggest that she was draped (Clark, p. 72). The notion of a Venus coming naked from the sea was an Eastern import (p. 73). Female nudes on pottery in the sixth century $\mathrm{BC}$ tended to be elongated. The elaborate curves and circles "from which the classic Aphrodite was to be constructed" (p. 73) came later. Clark posits that Polykleitos, in the Munich Girl of circa 400 BC shows the perfection of the line that sweeps from a cocked hip to "the sphere of the breast, and the long, gentle undulation of the side that is relaxed" (p. 80). 
Corpus Mundi. 2020. Toм 1. No 2 | ISSN: 2686-9055

Представляя тело | https://doi.org/10.46539/cmj.v1i2.21
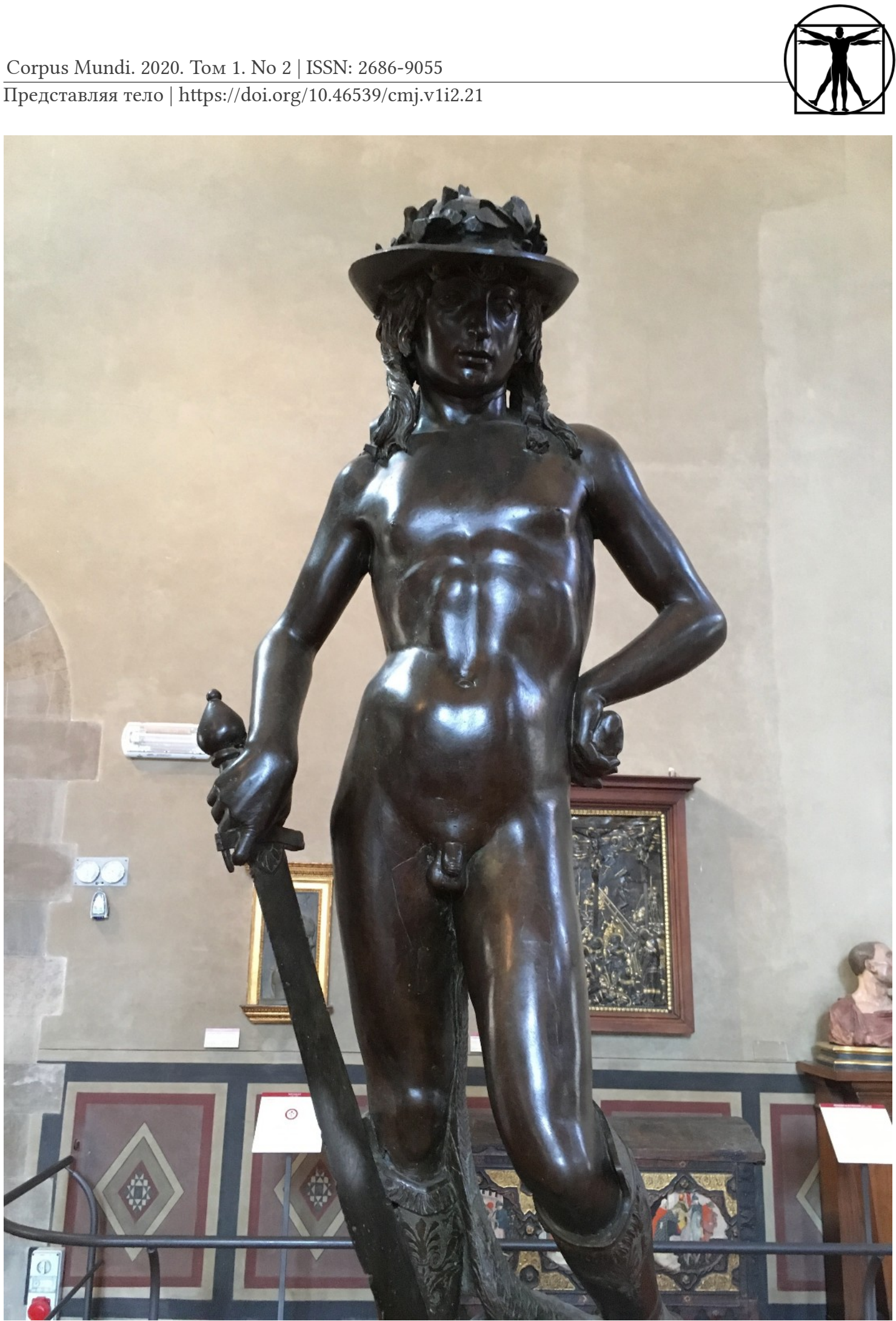

Figure 1. David. Donatello. 1430-1440 

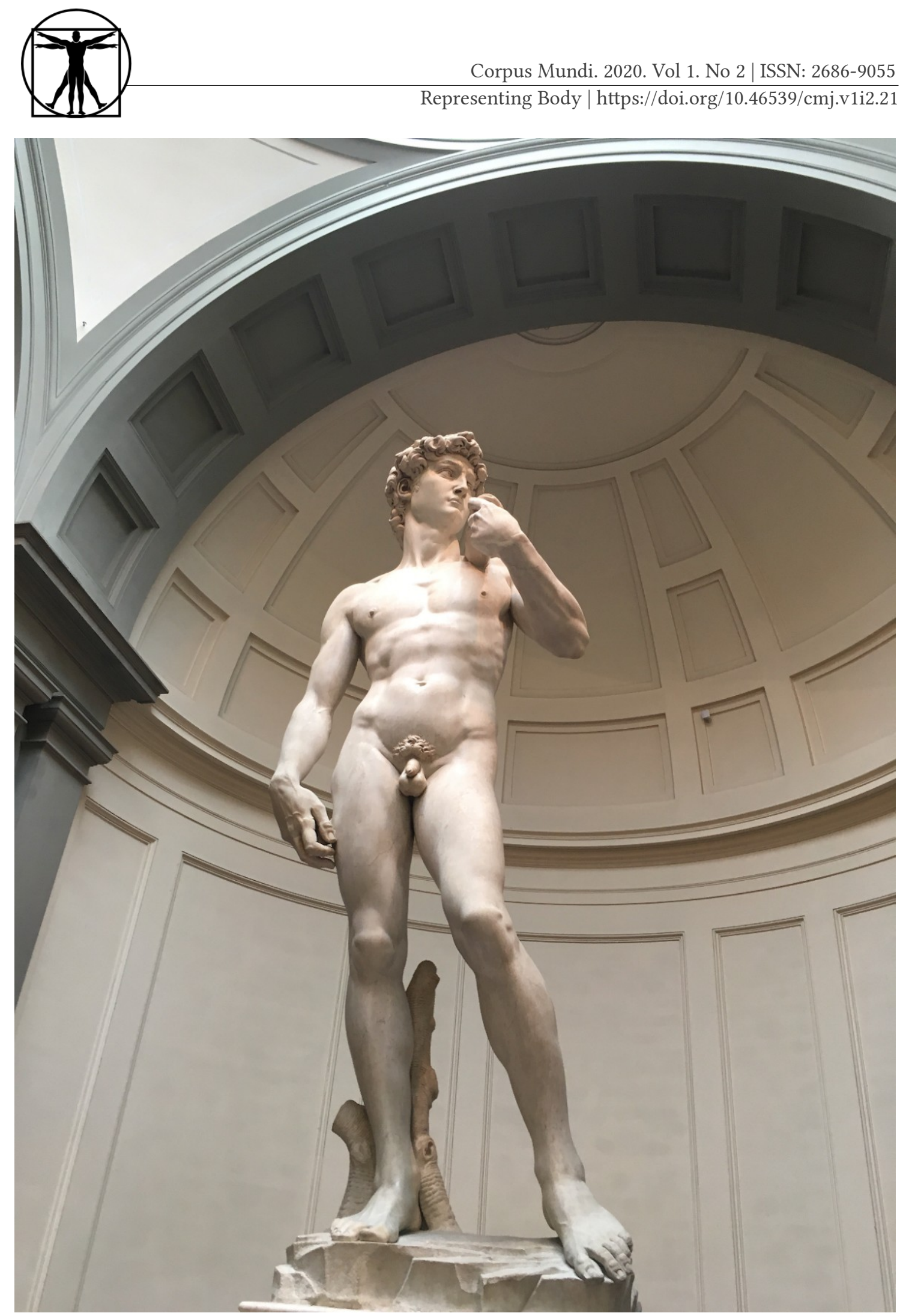

Figure 2. David. Michelangelo. 1501-1504

The balance and tension and the sensual line that unites the parts of the body has, to Clark, become synonymous with the female nude and the notion of beauty attached to it. For him, Rubens was to the female nude 
what Michelangelo had been to the male-someone who perfected the form and added to it-mainly, sensitivity of observation and also the erotics of the surface, which became textured and took on colors that would be added to by Rococo artists such as Boucher and Watteau (p. 148). Until this time, the front side of the female form had been considered the most important, perhaps the backside considered overly sensual such as that of the Hermaphrodite. Perhaps because of this sexual insinuation, female bottoms become important in the eighteenth century (p. 150). By the nineteenth century the female body began to take the place of the male one in academic studies of the nude, probably because of Ingres and the meticulous way that he observed the bodies of women (pp. 158-159). Up until this point in art history the female nude was often placed within a narrative - groves, woodlands, the bath, etc. Nature or idealized interiors were common. While male nudes also had their origin stories or contexts-the associations with Apollo or the story of David and Goliathnothing quite prepared the world of art for Manet's Olympia (1863), in which the woman, a prostitute, looks at the viewer with a stark, unmistakably naturalistic stare.

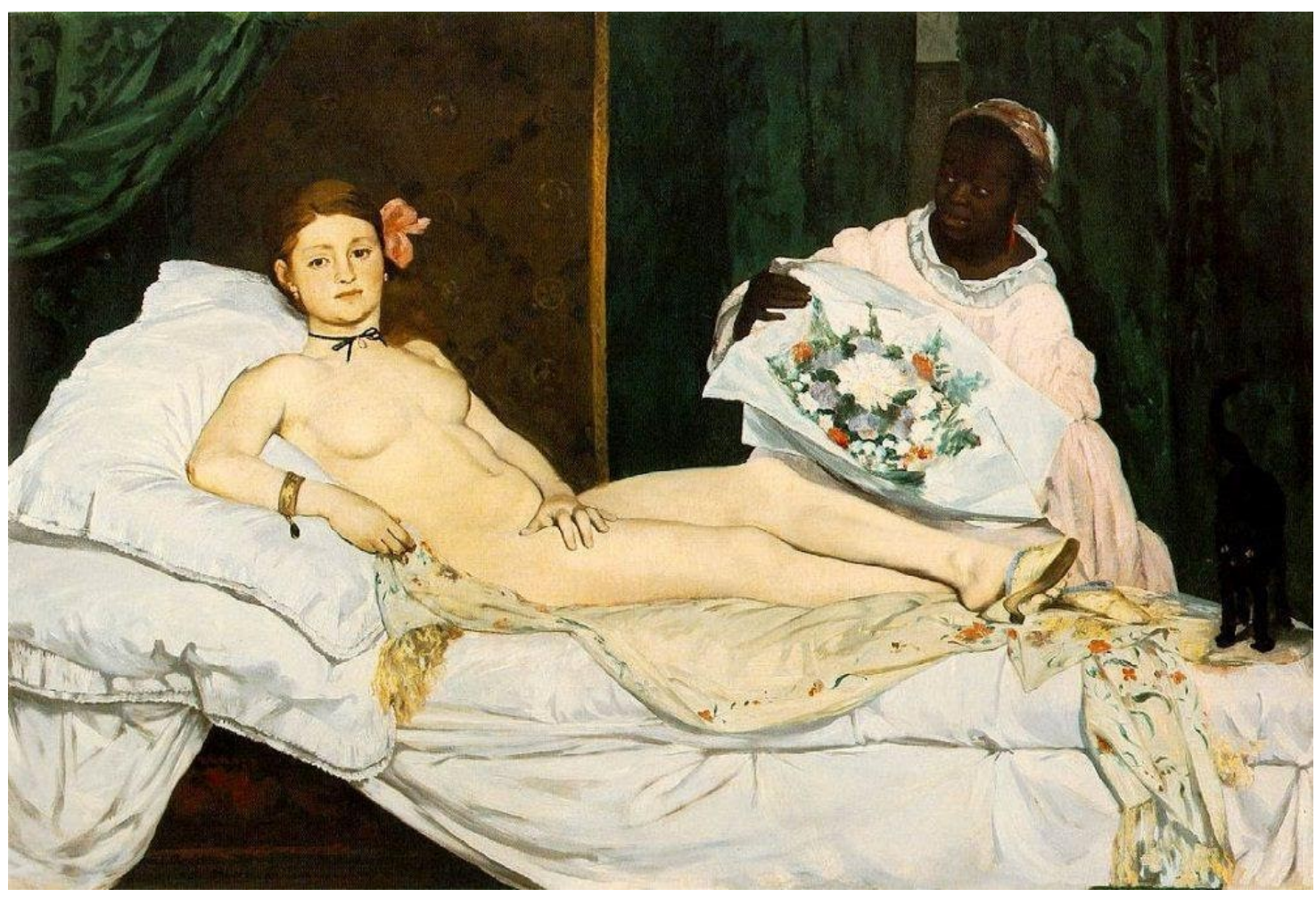

Figure 3. Olympia. Édouard Manet. 1863 


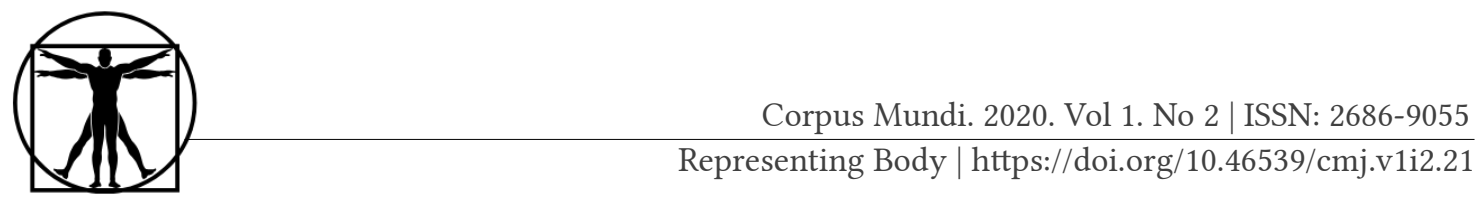

While artists had long drawn from actual women, they were also often idealized or somehow softened (p. 164). Manet, like Lautrec, refused to do that and the late-nineteenth century was the first time that the nude became naked-or the female nude a woman. Only Renoir, from this period, seemed to continue to see the nude as a viable tradition in its own right, though he managed to apply the lessons of Impressionism to his treatment of them.

Even now, when people discuss the desirability of a specific body or body type or part of the body they do so by alluding to sculptures or paintings of the Western tradition - parts of a canon, while hardly inviolate, that is useful as a frame of reference. While porn on film is hardly the same thing, it is part of the tradition of representations of the body that are meant to be studied for their aesthetic and erotic attributes. Clark goes on in his study to take on the notion of movement or action in nudes. Just as pornography has existed for generations as a still photo or model - the Playboy pinup or the Athletic Model Guild "art photograph"-and as film, video, or digital loops or movies, sculpture and painting have dealt with the balance of combining the two-how to show movement in a still image. For Clark, the notion of the athlete in movement allows for the artist to find a way to balance the arms and legs with the torso by carrying movement through the torso and freeing it of any stiffness (p. 178). The torso becomes the focal point, but the limbs are connected in a fluid, elegant pattern. For Clark, the sine qua non of this effect is the Diskobolos (460-450 BC) of Myron. The cinematic attempts to represent complex, continuous actions on the metopes of the Parthenon are unsuccessfully stiff and static for Clark (an opinion not necessarily had by others), but he argues successfully that the work of Myron, in its economy of the fluid line, suggests, as Rodin would argue about nudes, seeing an action at two different moments simultaneously (p. 180). If Greek sculpture had tried to show the body in repose before it might do almost anything, now the problem was showing the body stopped in a moment of action (p. 180). While this opposite state seems more problematic for Clark, it might now remind us of the two kinds of still images that we still have in porn - the poised publicity still and the freeze frame from an actual film. 


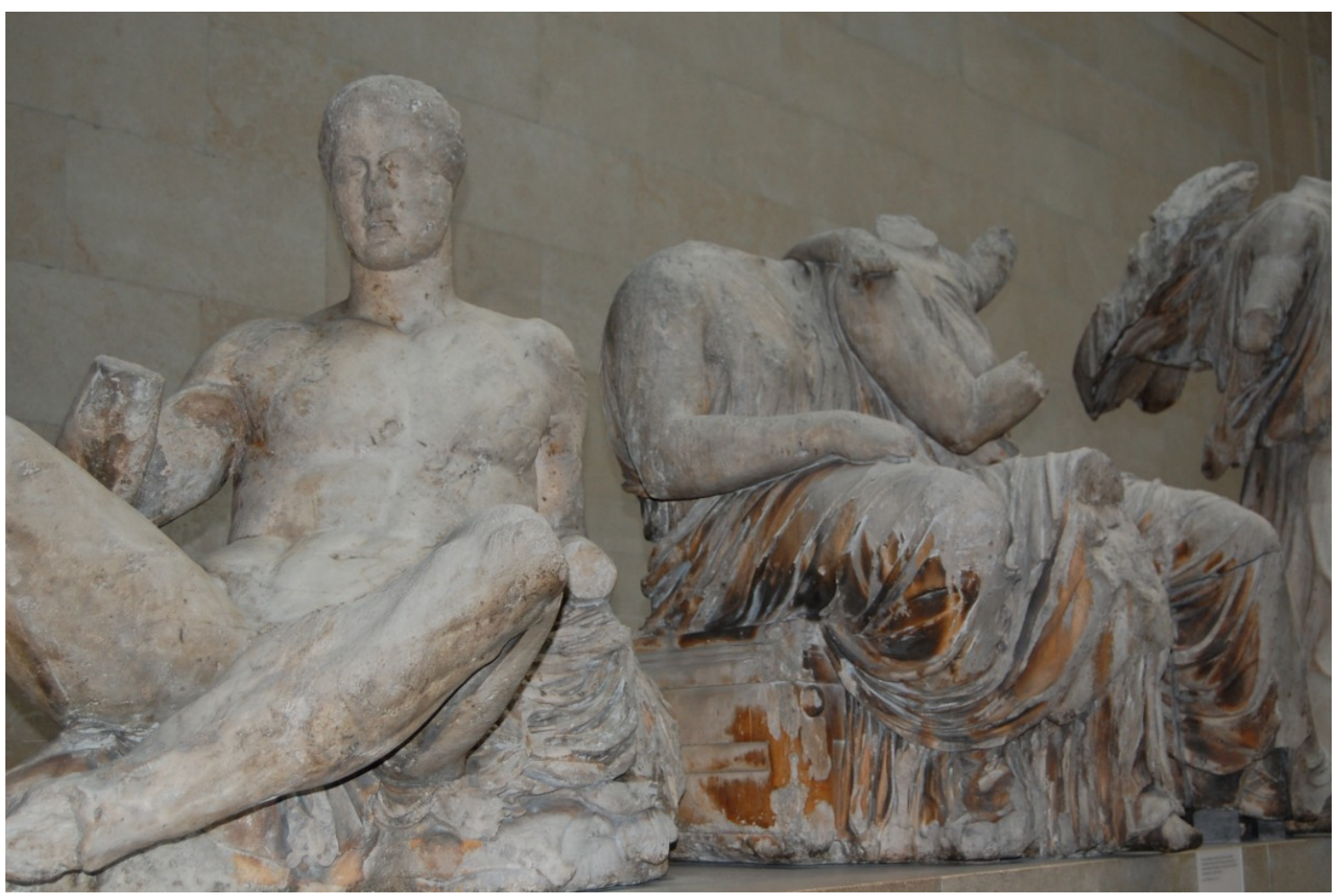

Figure 4. The Parthenon frieze. British Museum

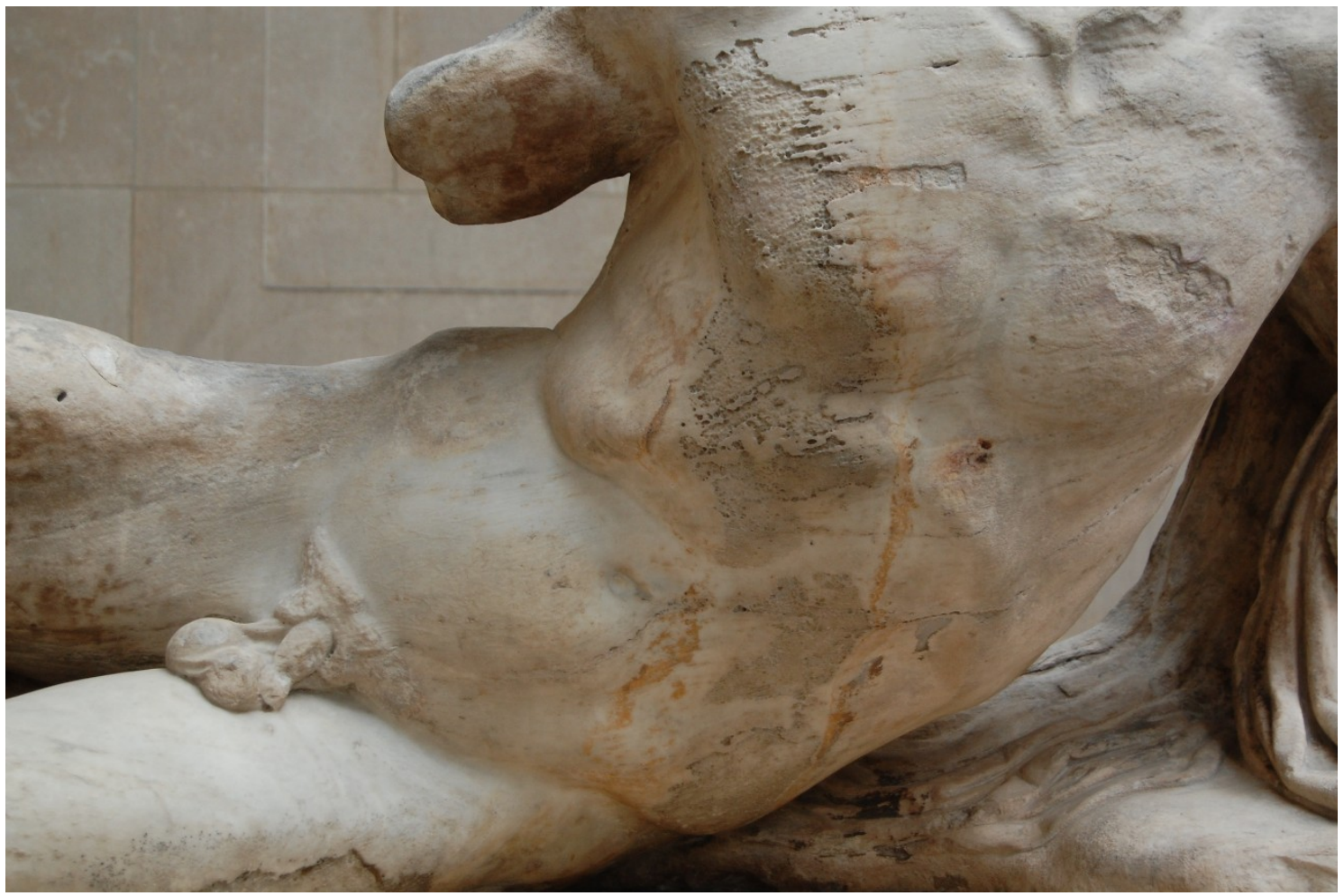

Figure 5. Detail of the Parthenon frieze. British Museum 


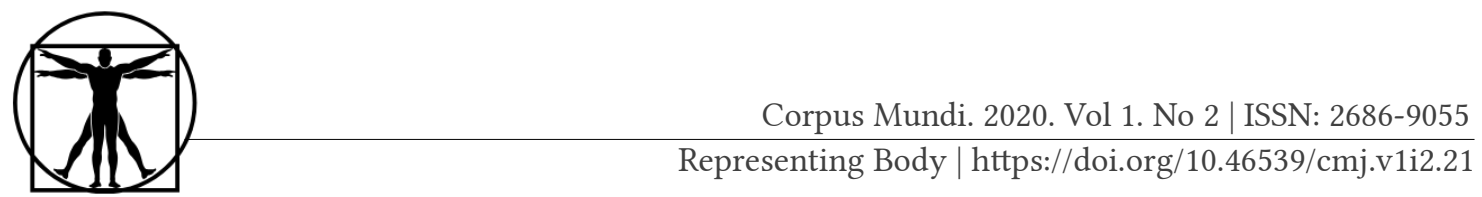

Representing the human body in states of movement or action continued to evolve for mostly cultural reasons. In late-fifteenth-century Florence, for example, it would have been in the form of male nudes in battle. Michelangelo, far from making perfect bodies like these, often creates nudes that seem to express an inner life more than a realistic outer one. If these figures were to step off the pedestal or ceiling, they would actually look grotesque (p. 209). By the end of his life the nude collapses completely into itself, the Duomo Pietà (1547) in Florence is completely without classical proportions and Michelangelo's confidence in the body has been replaced with an almost Gothic spirituality (p. 259). By the time of the drawings by Michelangelo of the Resurrection (1532; The Last Fudgement, 1536-1541) in the British Museum, Michelangelo depicts Christ floating up to heaven, as though finally freed of the body (p. 307). Once again, for Clark, the female nude took the place of the male nude by the eighteenth century, with Rubens once again leading the way. What are muscles in early Michelangelo becomes skin in Rubens, the surface becoming expressive (p. 265). Perhaps like late Michelangelo the surface starts to become semi-abstract, like Rembrandt's self-portrait in Vienna, and to break down at the level of the skin. By the time of Degas the female nude had become, once again, more animal-like and the nude had taken on more of a connection between art and life itself (p. 223). In sculpture, Rodin brings a chapter of classical art to a conclusion. While some of his sculpture could be, to Clark, overdone and exaggerated, it is, like Wagner, for a purpose, becoming vulgar to express our modern times (p. 271).

The classical tradition that Clark traces is, of course, one based upon the Greek ideal. An alternative tradition, as he terms it, can be found in the early Medieval, or perhaps more accurately, Gothic body that shows the human form not as nude but as profoundly naked, "an object of humiliation and shame" (p. 309). This rendering of the body had its own conventions but was built upon the conviction that the body expressed almost the opposite stance to the Attic one. As Clark summarizes, "While the Greek nude began with the heroic body proudly displaying itself in the palaestra, the Christian nude began with the huddled body cowering in consciousness of $\sin ^{\prime \prime}$ (p. 311). The primary plastic embodiment of this change was in making the focus of the body the curvature of the stomach as opposed to the hip, which creates an upward thrust that equates with "energy and control" (p. 318). The stomach, by contrast, "is created by gravity and relaxation" (p. 318). The stomach "does not take its shape from the will but from the unconscious biological process that gives shape to all hidden organisms" (p. 318). 


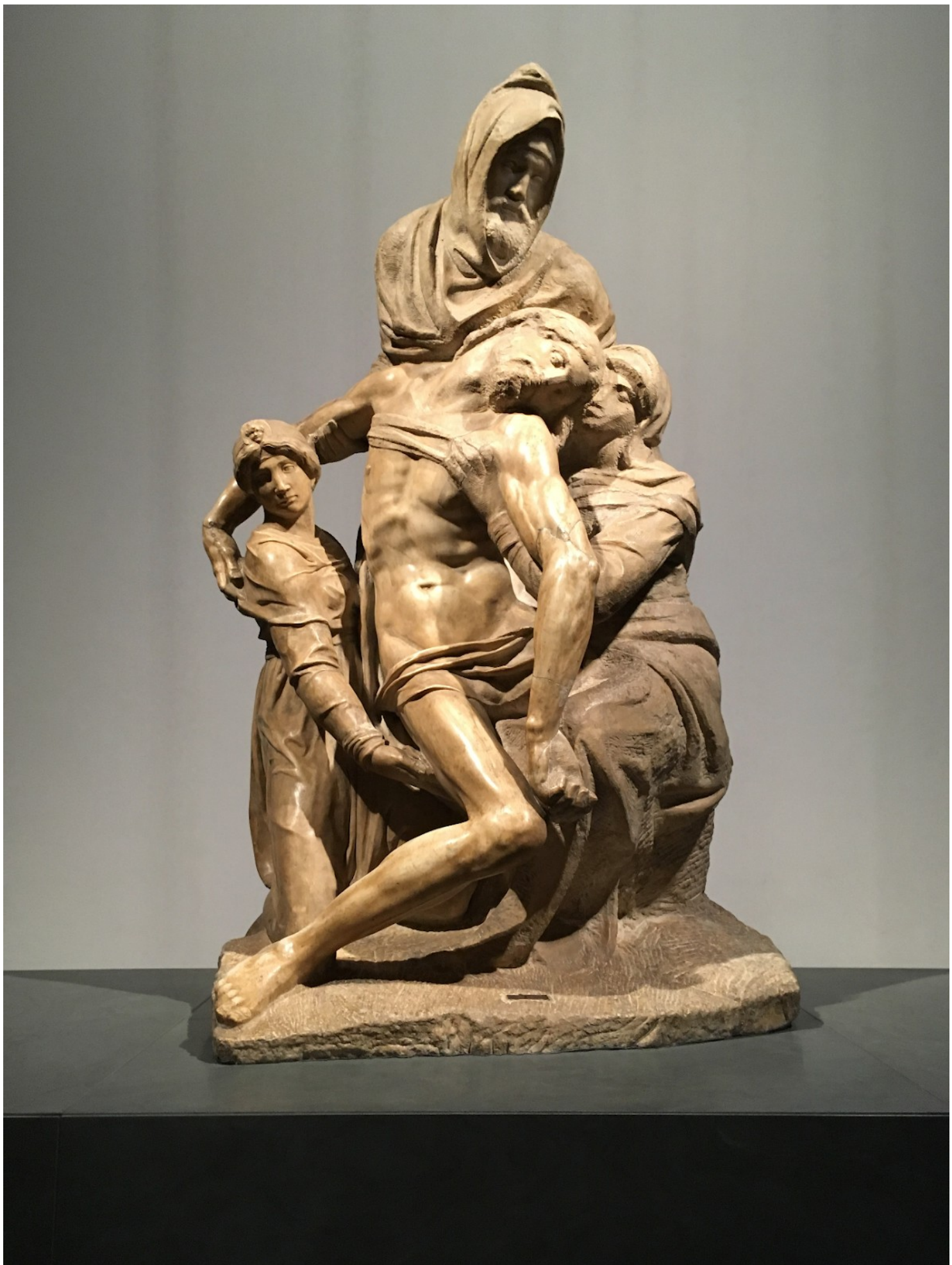

Figure 6. The Deposition. Michelangelo. 1547-1555

The Gothic female body, with its small breasts, long torso, and sagging stomach can be seen as an alternative representation of the nude, but can it be seen as the naked complement to the more "abstract" classical 


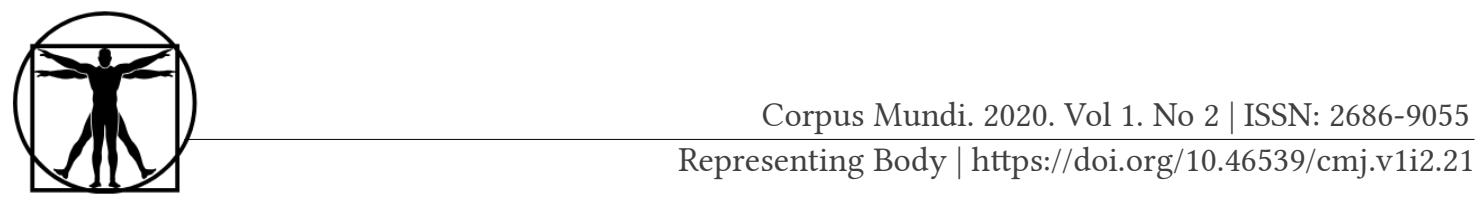

nude? And does it cross time to become, in the future, any representation of the body that sees it as naked-or renders it in an un-idealistic way? Clark ends with these concerns, and we might take them further. Is porn an attempt at the Greek or the Gothic body? In Eyes Wide Shut (1999) Stanley Kubrick seems to render perfect, perhaps classical bodies, but one of his inspirations was Klimt and the German Expressionists, who were certainly creating Gothic bodies if anyone ever was. In Schiele's nude selfportraits "seemingly decaying bodies posed in sexually exhibitionistic ways displaying his groin and genitals, morbidity mingles with eroticism, suffering with lust" (Rewald, p. 55), the effect that Kubrick attempts to create at least in terms of the film's constant mixing of death and sex. For Clark, the Modernist move toward the nude "as an end in itself" was actually a movement back toward Greek classicism in which the nude was supposed to express an idea or an abstraction at the precise time when artists began to think of art as "an intellectual, not a mechanical, activity" (p. 351). The naturalistic bodies rendered from real life are replaced with the extreme minimalism of Matisse's nudes. Freed of narrative and of associations, the nude becomes simply itself - its own pure form.

In a later book entitled Feminine Beauty, which Clark considered more of a précis or outline of the subject, he ends the book with photosthe last one of Marilyn Monroe. Perhaps Clark saw photos as the next metamorphosis of the nude. Though Clark does not claim photography as an area of his expertise-indeed, he didn't deal much with the contemporary at all-he must have thought that photography changed the notion of the nude in some way, if only in the attention that photographers give to the nude human form. Photography continues to develop the theories undergirding the notion of ideal forms, or the representation of the body visually, in the scientific work that has been done on perspective, proportion, and how the eye translates two-dimensional (and even three-dimensional) forms into the illusion of the physical body. This more mathematical approach is often combined with an art-historical interest in stylistics and how the technical display of the body changes over time and is linked to aesthetic choices.

Erwin Panofsky argues that there the differences between Egyptian and Greek representations of the body stem from the difference between what the artists are trying to represent. For the ancient Greeks, sculpture was an attempt to bring an already living being to life, while the Egyptian purpose was for art to preserve the body for later reanimation ("reenlivened") (Panofsky, p. 61). The sculpture of the body is a mere "imitation" (p. 62) or form (p. 61); for the Greeks, it is "reconstruction" (p. 62) and "function" (p. 61), respectively. The mechanical aspects of Egyptian art 
were systematic rather than observational. Any artist in the kingdom would know where an ankle should go or what the proper proportion of it would be. An underlying geometric system governs art. For this reason, Egyptian art rejects the notion that limbs, for example, are a part of an expressive movement such as we see in Greek athletes, the position of limbs are instead "purely local changes in the positions of specific members" (p. 57). Egyptian artists likewise eschew foreshortening, the "apparent extension of the plane into depth," and the flattening of any "three-dimensional volume" in sculpture (pp. 57-58). The results of these formulae were the creation of the familiar conventions of Egyptian art-sculpture (with some exceptions) is either fully frontal or in profile; two-dimensional painting presents the body frontally but the head in perspective (p. 58).

The system of proportion developed in Greece had a different goal: to capture the real. As systemized by Polykleitus, the rigid sculptural influences of Egyptian art that can be seen in the early Kritios boy sculpture of the Archaic period slowly gives way, one innovation after another, to the pre-Hellenic high period of classical sculpture. Though we may take this style for granted now, it was, of course, not to be followed during most of the history of art in the West. Byzantine art followed a different formula and Gothic art its own. The latter brought sculpture and painting back to the Egyptian ideal in which a design was placed over representations of the body that governed how bodies would look with the naturalistic aspects not only secondary but even resented. The Renaissance restored the Greek approach and, for the first time, truly codified it in a mathematical way in order to render it not only natural but also spiritual-a Neo-Platonic yoking of the body to the soul (p. 90).

As E. H. Gombrich argues, it is important to keep in mind that Greek art is based upon a limited number of repeating types, and in this sense, it is just as constricted as Egyptian art, maybe even more so (p. 142). The type in Greek art is based on nature, but an idealized form of it-bodies as perfect specimens of the athlete, soldier, etc. While some aspects of nature are rendered-pubic hair, for example - some, such as underarm hair, are not (Scranton, p. 224). The conventions change, however, over time, from the semi-abstraction of the Archaic period to the increasing particularization of the body and its details in the Hellenistic era (p. 224). It is not always possible to tell one male (or female) figure from another. The props given to the character are sometimes important in this way, though what is paramount is the human figure (p. 238). The narrative context, however, is inherent in some figures, such as the self-consciousness of Praxiteles' Aphrodite (fourth century $\mathrm{BC}$ ), which includes the spectator in the narra- 


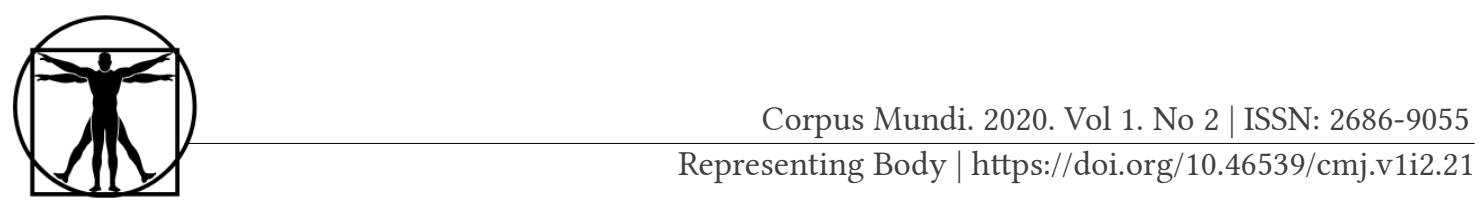

tive, completing the circuit. This use of psychology gives Greek sculpture of the Classical Period a spatial as well as temporal dimension (p. 251).

It's also important to remember that our associations with Greek sculpture now, and especially in the past, assumed that they were white marble-either from age or white-washed, literally, on purpose, the original paint having been removed. Even knowing this fact, it is often difficult for us to think about the sculpture of this era without consciously or unconsciously placing meaning on the whiteness, the marble becoming a kind of skin of its own, the blue veins of some of it seeming to be the real veins of an impossibly-white person, the color seeming to be as much an ideal as the shapeliness of the body represented. Even knowing that the free-standing sculptures and freezes that represent gods, demi-gods, and heroes were always painted, we forget to see the bodies represented as having skin tones, hair, eyes that were not only a form of realism but also non-white. European culture has created a simulacrum of ancient Greek culture in which we think of it as white, when it was not. Likewise, Modernism makes us want to see the Acropolis or sculptures of Hermes or Venus as white because it would make them more abstract, would lessen their realism, which might not be wholly convincing and make them instead pure forms in their monochromatic state. At the Acropolis Museum in Athens color is being restored to some of the statues. Likewise, it is important to keep in mind that while the representation of the body may have begun with Greek sculpture as a major influence, if only because of the total male nudity, that bodies were represented in various ways throughout the Middle Ages, the Renaissance, and during the post-Enlightenment period and that most of the artists and craftsmen who made them used realism as a way to inject eroticism into the figures. That is, a Medieval reliquary of Christ's semi-naked body or a painting of St. Sebastian or of female saints might have skin tone, rosy cheeks, even hyper-realistic wounds as a way to express the materiality of the body. In this sense, they become stand-ins for the real thing, sometimes uncannily so in the case of three-dimensional sculptures or figures that allow the spectators to imagine the physicality of the suffering or ecstasy more completely, even to hold parts of a mock body as a part of a religious purging of emotions. The original realism of Greek and Roman sculpture has to be seen, then, as a part of a continuous tradition that has tried to represent the body for what it actually is, not just what it might be, even when the body is of a god ${ }^{1}$.

1 Recent interest in the body in visual art can be seen by several high-profile shows at prominent museums such as 'Life Like: Sculpture, Color, and the Body', which ran at the Met Breuer from March 21-July 22, 2018 in New York and 'The Renaissance Nude' at the Getty Center in Los Angeles, which ran Oct. 30, 2018 to January 27, 2019. The curation for the former show presented a 
Clark's approach to the nude is a useful way to continue to think about the nude in classical art and how it might help us in the close reading of the body and its representations. Botticelli's Venus (1490) arguably represents one of the most perfect depictions of the human form ever achieved in art. Painted in the 1480s, after the more famous The Birth of Venus (1484-1486), this version is earthier, subtler, and sexier at the same time. With her young, youthful face and braided hair, Venus stands in the classical position that dates back to Praxiteles with her hands loosely covering herself modestly as though stepping from a bath. Her face floats on shoulders that form a point and that then move down to an elongated body, especially the torso and slender legs. The hands, feet, and face are slightly larger in their design. The black background and dramatic position on a ledge add to the emphasis on the corporeal. Botticelli emphasizes her skin using shadows and a skin tone with red undertones, her thighs and the musculature of her stomach setting the erotic intention of the painting and sealing it with the see-through wrap she wears over her shoulders, which emphasizes her nakedness even more. What is remarkable in some ways is the incredible contemporaneity of Botticelli's female nudes-they have become an ideal within the culture and in this way never age. The representation of the female body as youthful, slim, with long hair is a type that is still with us, adding to his paintings' ability to seem timeless. It is difficult to underestimate how much influence art has on our own ability to see the contemporary nude body, the ideals of the Classical period, as reimagined through the Renaissance, continue to exert a profound influence on our notion of what bodies should look like even if they rarely do. Artistic bodies are not realistic bodies, and even actual contemporary bodies that are considered attractive deviate from artistic bodies in profound ways. On the one hand, we need to see actual bodies for what they are, to celebrate the bumpy and imperfect realness for what it is and how it is not only sexy but also the only bodies we can touch and feel and really know. On the other hand, we need to remember that artis tic representations of bodies are above all else expressions of an idea of the body. No one could really look like the Venus nor would want to in real life. Botticelli was painting something linked to real life in its sensuousness, but as with Greek Classical sculpture, it was never meant to be a replacement for the body, or the body come to life.

number of different ways the body has changed over time and been represented realistically and erotically in different media-from dolls to cabinets filled with recycled human blood. The show was particularly helpful in highlighting the use of color in Ancient sculpture of the human nude, which was never the abstract white that we still see today. Another show at the Met Breuer, 'Obsession: Nudes By Klimt, Schiele, and Picasso,' July 3- October 7, 2018, featured the nude as well, especially the bodies of prostitutes and other models in Vienna during the years that Klimt and Schiele worked there. 


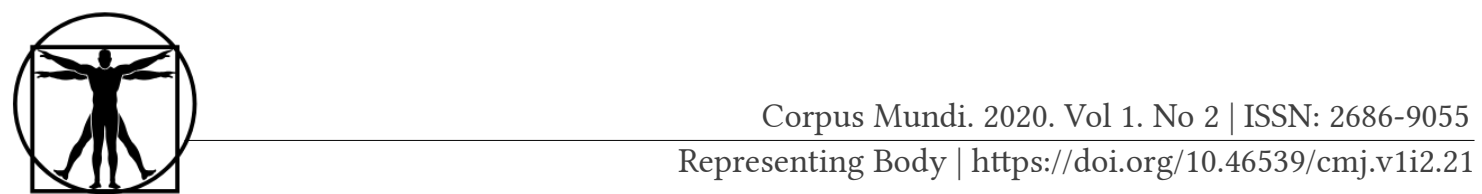

What the Renaissance set into motion was a desire for a scientific representation of the body that was at one with the attempt at the realistic representation of space. The reinvention of one-point perspective allowed for the placement not only of the eye in space, but the body as well. Three-dimensional architectural space and landscape became the containers and backdrops for bodies and the appropriate measurements used to obtain a realistic sense of depth were soon applied to bodies as well. That Vitruvius' emphasis on proportion in architecture in the rediscovered $D e$ architectura (30-15 BC) spurred attempts by artists of the Renaissance to render an ideal body can be seen in the Vitruvian man by Da Vinci (circa 1490) and combined with a new interest in not only continuing classical learning but in adding to it by bringing to representations of the body the new realistic analysis coming from anatomical drawings and vivisection. Yet even Da Vinci, famous for the latter as well, to some extent idealized his drawings, combining several different versions of the same flayed body part in order to find the ideal one, the essence of what was being represented, even in death and dying ${ }^{1}$.

The world of Western art and literature contained, from at least the Renaissance to the eighteenth or nineteenth centuries, much of the same fascination with sex acts that we have today. One need only look at the translation into English and French of Friedrich Karl Forberg's Manual of Classical Erotology (De Figuris Veneris) to see a detailed and objective discussion of not only sexual positions but such topics as masturbation, bestiality, anal sex, and the best way to remove unwanted body hair. Written as an anthology of Greek and Roman writing, it is a commentary on Antonio Beccadelli's poem, Hermaphroditus [Antonii Pandarmitae Hermaphroditus]. Privately printed, it was, in the Victorian world, parallel to the work of something like Teleny (1893) - porn written for a select allmale clientele ${ }^{2}$. But read today, one is struck by the parallels to a porn site that its chapter titles might have-"Of Copulation," "Pedarastia," "Irrumation," "Cunnilingues," "Tribads" - even if some, but not all, of the names may have changed over time. Held together by the figure of the hermaphrodite, the book makes clear our connection to the ancient world, to the body as a source of knowledge, and to the slipperiness of gender that actually resides in the microcosmic level of details about sex that porn represents.

1 As Davide Gasparotto notes, "Leonardo suggests that after practicing drawing from living models, the students would select 'from the best limbs and best bodies' ('delle migliori membrane e migliori corpi')" (249).

2 For more on Teleny, see chapter two of my The Aesthetics of Self-Invention: Oscar Wilde to David Bowie. 
Of the many ways that we have for explaining the combination of male and female characteristics in one body, androgyny implies a mixing of attributes while hermaphroditism suggests a placing of male characteristics beside female ones in a way that leaves the two sexes distinct-a map of contrasting desires that confuses the senses or fools the eye depending upon the angle from which one sees the body. The hermaphrodite, in the classical Greek sense, suggests Plato's theory of the combining of the sexes (though for Plato there were three) and preserves the supposed contrast between men and women - the complementarity - that Plato's theory is often reduced to. The often-copied Sleeping Hermaphroditus (second century BC) makes the popularity of the form clear, its erotic potential seemingly signaled by the sheer number of versions of the original that are spread out over Italy and France.

The popularity of the hermaphrodite, at least in art, can be attributed to the necessity of leaving the sexes distinct yet seeing them combined in one body and forcing a dialogue between the two that suggests both the seeming inevitability of two sexes and the destabilizing suggestion that this is a construct, a fiction, that unsettles the very notion of the materiality of the body itself. An artistic definition is, of course, not a scientific one, but whether artistic or scientific, the concept seems to suggest an ability to move back and forth between the sexes or a mixing of codes that somehow refuse to define themselves-an ultimate undecidability, a threshold for defining the limits of sex by refusing to find a word for it. In this sense, hermaphrodite might always be seen as a definition that is defined only by that which it is not: decidedly one sex or the other, or not a sex at all. It is, as Ferdinand de Saussure might say, a negative definition. Its value is purely situational.

Androgyny, by contrast, is about the blending of the sexes. While this effect, as well, might be one that forces some kind of definitional design, the outcome is often different. If hermaphroditism forces some kind of thinking about biological sex, perhaps a thinking that does remain purposefully unintegrated, that approaches a limit without transgressing it, androgyny seems to force the two sexes to intermingle and produce a third term that seems firmly rooted in either one sex or the other. A purely aesthetic concept, rather than a scientific one, androgyny can, in theory, be anchored to either sex-a man with feminine characteristics, or a woman with masculine ones. 

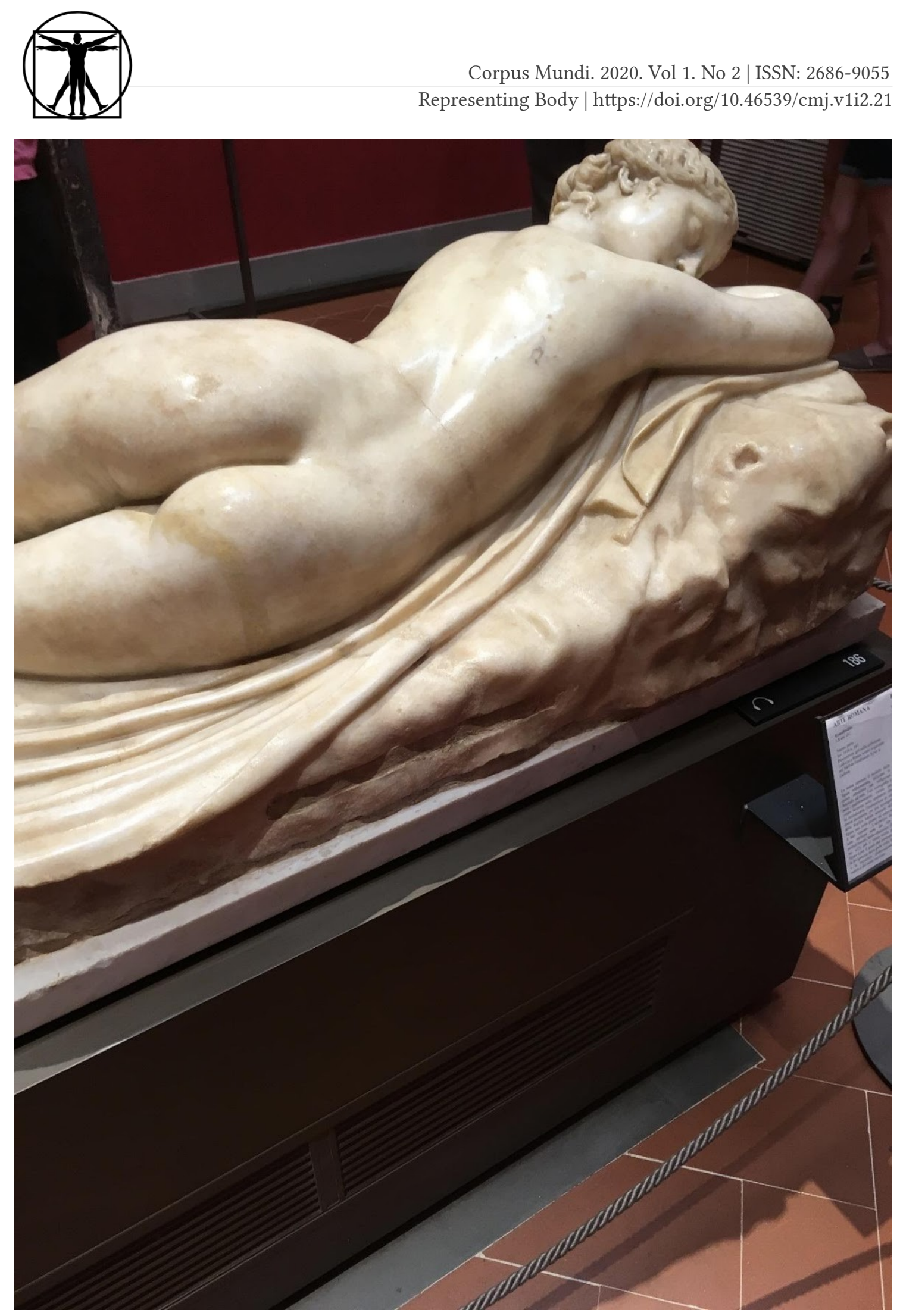

Figure 7. Sleeping Hermaphrodite. Polycles. 155 BC 


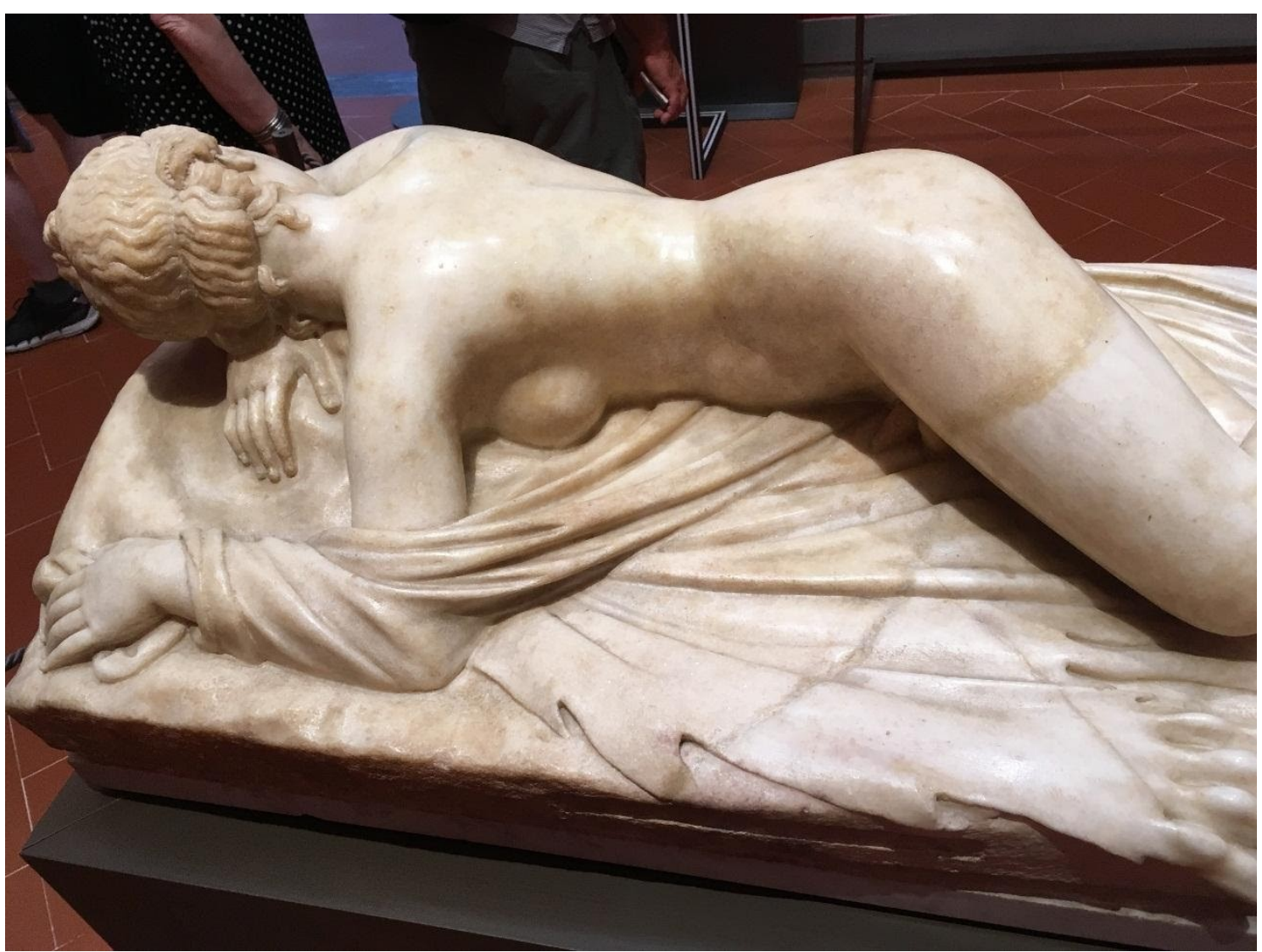

Figure 8. Detail of Sleeping Hermaphrodite. Polycles. 155 BC

While the ultimate limit of androgyny may be an undecidability as well - a third term in which male and female characteristics blend into an unknowable fusion - in reality, it often skews one way or the other. That is, androgyny is a template that softens the male form or hardens the female one in such a way as to produce a non-normative response on the part of the viewer, one that suggests the limits to our ideas about what constitutes the sexes. In this sense, then, androgyny seems to always be a value judgment that marks the outer reaches of the socially accepted norms of sexual markers. In fact, as a social construct, androgyny is really about gender, not sex. It is wholly a construct of culture, even if bodies may be described objectively, and materially, as genuinely androgynous. It is also an effect that may be created by a person who manipulates the male and female cultural norms of their environment. In that sense, it is also relational, like hermaphroditism, in that the definitions of masculine and feminine are extremely local and bend more easily than we might think by where one is located - urban or rural, factory or bar, upstate or down, etc. As with the codes of sexuality, gender codes are created to be read, decoded, and understood as a comment on the limits of definition 


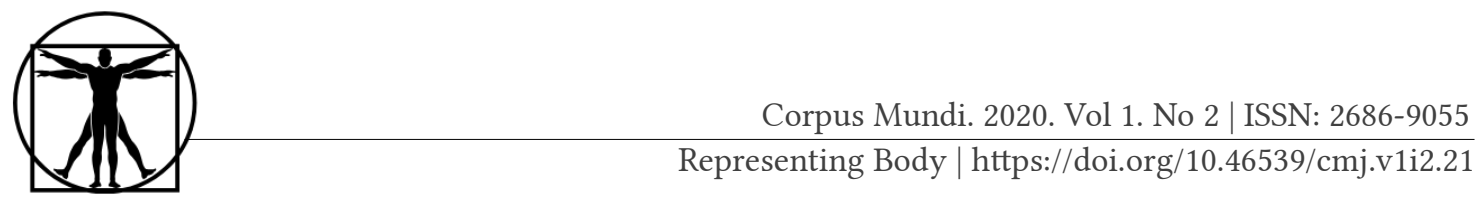

and re-definition. In this sense, it is impossible not to read the Greek statue of the hermaphrodite as a comment on Ancient Greek culture, to have its meaning within it. To the extent to which this culture has influenced the Western world, and global notions of art and beauty worldwide, one has to read the statue in two different ways. Unfortunately, we do not know much about the statue's origins, though we do know a lot about Greek definitions of sex, gender, and sexuality.

From the Symposium and elsewhere, J. K. Dover, Michel Foucault, David Halperin, and others have theorized the Greek ideal of male and female sexuality. The male body in Greek sculpture famously presents the body as a golden mean, but the gender characteristics are culturally specific. The male body is firm and athletic, but also softened somewhat. Though Greek plays by Aeschylus, for example, equate feminine characteristics with the East - with Persia, specifically, or Troy - they exist as well in the statuary, which grew out of Eastern sources, especially Egyptian ones. While one characteristic of Eastern inspiration was toward geometry or abstraction, another was toward the feminine or androgyny, though of a highly specific sort. Greek statues by Praxiteles and others at the height of the classical period temper this softness to provide some tension between the two poles. A distrust of the feminine, which can be seen in the patriarchy of Athenian culture, which denied women citizenship or even much of a public role outside the house, also kept the representation of the male body from being too static or feminine. Hence the male body is dynamic, in contrapposto, and decidedly male overall. The aesthetic of the male body, however, combines both genders, as bodies always do, and even in what is seen as perhaps the primary or originary definition of male beauty, the feminine creeps in to challenge, or change, the formulaeven if it is ultimately there to be banished.

Michel Foucault notes in his posthumous The Use of Pleasure that while "classical figure sculpture paid more attention to the adult body" (p. 200) it was certainly also clear that in the "sphere of sexual ethics, it was the juvenile body with its peculiar charm that was regularly suggested as the 'right object' of pleasure" (p. 200). Foucault goes on to observe that "it would be a mistake to think that its traits were valued because of what they shared with feminine beauty. They were appreciated in themselves or in their juxtaposition with the signs and guarantees of a developing virility" (p. 200). In the high classical period, in other words, "[s]trength, endurance" were seen as protection from "softness and effeminization" (p. 200). It was not until later in the period, that "feminine ambiguity... would be perceived... as the secret cause... of the adolescent's beauty" (p. 200). Though the seeds of this possibility may already be present in the fourth 
century, during "the classical period" femininity was "more something from which the boy needed to protect himself and be protected" (p. 200). Masculinity was dominate, though in a nascent form: "Virility as a physical mark should be absent from it; but it should be present as a precocious form and as a promise of future behavior: already to conduct oneself as the man one has not yet become" (p. 200).

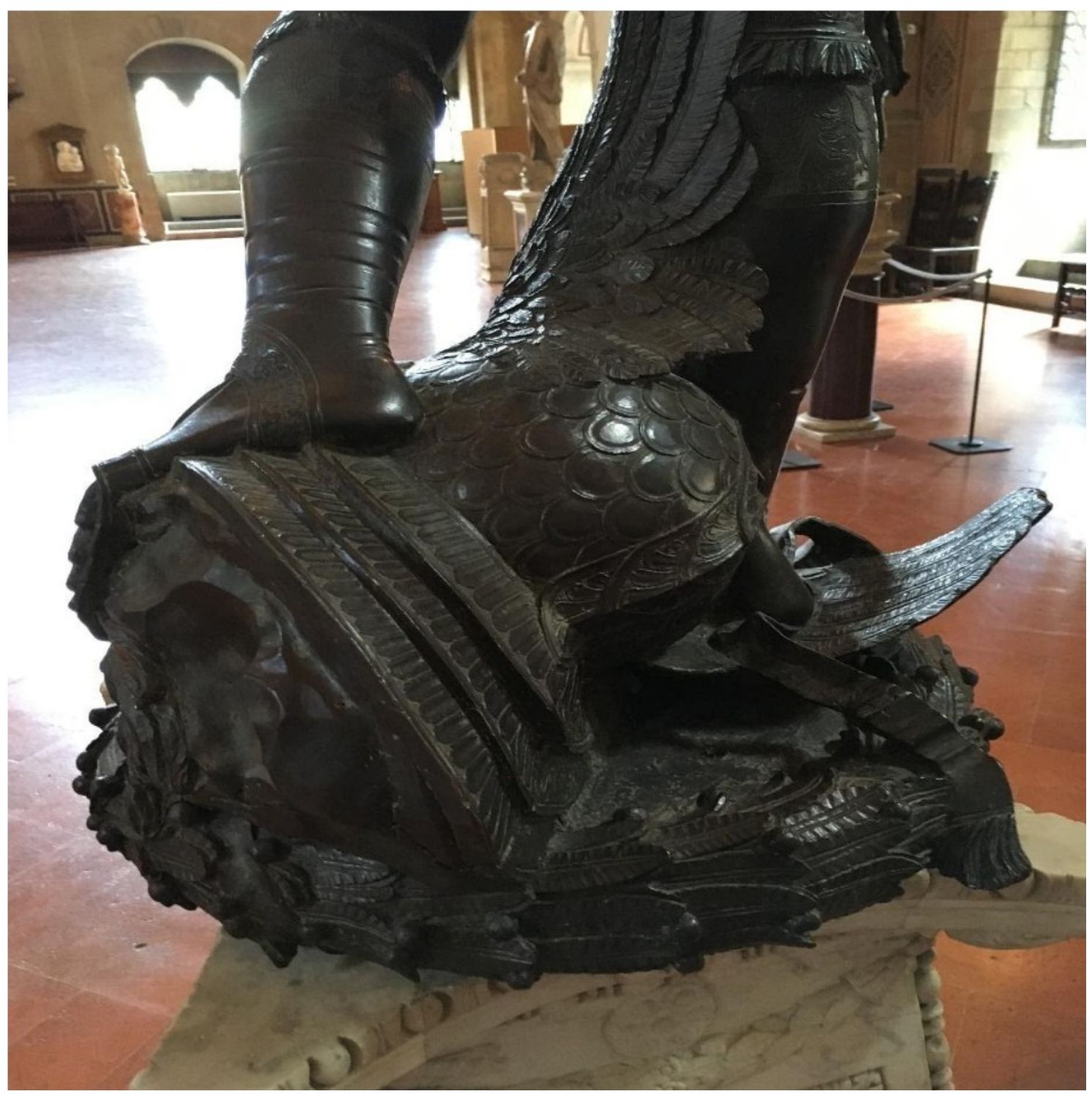

Figure 9. Detail of David. Donatello. 1430-1440

While we may not be able to talk about the Greek ideal as hermaphroditic or androgynous, by the time Greek ideas are revived during the Italian Renaissance the male and female forms have more formally blended. As the first freestanding male nude of the Renaissance, Donatello's David is striking as an example of Early Renaissance androgyny. 
While the beauty of young men was a subgenre of Renaissance portraiture, the mixed codes of Donatello's strikingly epicene rendering-from the curls and helmet to the eagle's wing that comes up from the bottom of the statue to stroke his thigh - renders the male form in terms that go quite a bit outside the Greek code of masculinity.

Donatello's statue, like all of his major works, is dense with information and detail and is wholly original in its expressiveness. The other great David of the period, by Michelangelo, returns the male form, to some extent, to the ancient Greeks, only with some characteristics changed, ones that were specific to Michelangelo's rendering of the ideal male form, such as compressed hips, or related to the Renaissance conceptual ideal, such as the enlarged hands of the David. The form, overall, fits the function of the subject matter, though with the added definition of Michelangelo's ideal body type. That his sculptures would ultimately tend toward the expressionistic, even semi-abstract, is there already in his willingness to bend the rules of realism, even more than the Greeks, to express an idea or overall artistic effect.

Figures 1, 2, 4, 5, 6, 7, 8, and 9 are photos taken by the author.

References

Clark, K. (1980). Feminine Beauty. New York: Rizzoli.

Clark, K. (1972). The Nude: A Study in Ideal Form. Princeton: Princeton UP.

Dover, K. J. (1978). Greek Homosexuality. Cambridge: Harvard University Press.

Forberg, F. K. (1966). Manual of Classical Erotology (De figuris Veneris). New York: Grove Press.

Foucault, M. (1985). The Use of Pleasure: Volume II of the History of Sexuality. Robert Hurley (Trans.). New York: Pantheon Books.

Gombrich, E. H. (1969). Art and Illusion: A Study in the Psychology of Pictorial Representation. Princeton: Princeton University Press.

Isaacson, W. (2017). Leonardo da Vinci. New York: Simon and Schuster.

Jameson, F. (2015). The Ancients and the Postmoderns. New York: Verso.

Kubrick, S., (Dir.). (1999). Eyes Wide Shut. Perf. Tom Cruise and Nicole Kidman. Warner Bros.

Panofsky, E. (1955). Meaning in the Visual Arts: Papers in and on Art History. Garden City, NY: Doubleday Anchor Books.

Pollio, V. (1968). De architectura. Trans. Lorenzo Cesariano. New York: B. Blom. 
Rewald, S. \& Dempsey, J. (Eds.). (2018). Obsession: Nudes by Klimt, Schiele, and Picasso from the Scofield Thayer Collection. New York: The Metropolitan Museum of Art [Distributed the Yale University Press].

Sedgwick, E. K. (1990). Epistemology of the Closet. Berkeley: University of California Press.

Список литературы

Clark, K. (1980). Feminine Beauty. New York: Rizzoli.

Clark, K. (1972). The Nude: A Study in Ideal Form. Princeton: Princeton UP.

Dover, K. J. (1978). Greek Homosexuality. Cambridge: Harvard University Press.

Forberg, F. K. (1966). Manual of Classical Erotology (De figuris Veneris). New York: Grove Press.

Foucault, M. (1985). The Use of Pleasure: Volume II of the History of Sexuality. Robert Hurley (Trans.). New York: Pantheon Books.

Gombrich, E. H. (1969). Art and Illusion: A Study in the Psychology of Pictorial Representation. Princeton: Princeton University Press.

Isaacson, W. (2017). Leonardo da Vinci. New York: Simon and Schuster.

Jameson, F. (2015). The Ancients and the Postmoderns. New York: Verso.

Kubrick, S., (Dir.). (1999). Eyes Wide Shut. Perf. Tom Cruise and Nicole Kidman. Warner Bros.

Panofsky, E. (1955). Meaning in the Visual Arts: Papers in and on Art History. Garden City, NY: Doubleday Anchor Books.

Pollio, V. (1968). De architectura. Trans. Lorenzo Cesariano. New York: B. Blom.

Rewald, S. \& Dempsey, J. (Eds.). (2018). Obsession: Nudes by Klimt, Schiele, and Picasso from the Scofield Thayer Collection. New York: The Metropolitan Museum of Art [Distributed the Yale University Press].

Sedgwick, E. K. (1990). Epistemology of the Closet. Berkeley: University of California Press. 